\title{
WALTER BENJAMIN E THEODOR ADORNO: O ESTUPOR DA FACTICIDADE À MEIA-NOITE DO SÉCULO ${ }^{1}$
}

\author{
OLGÁRIA MATOS ${ }^{2}$
}

A correspondência entre Benjamin e Adorno oferece ao leitor a contribuição mais valiosa na compreensão do livro das Passagens de Benjamin como também da gênese do pensamento de Adorno. As cartas tematizam a questão do mito na modernidade, central tanto para a filosofia de Benjamin desde "A felicidade do Homem Antigo" de 1916, passando pelo Drama Barroco de 1924 até as Passagens, trabalho interrompido em 1940, como também para Adorno, do ensaio “ O Conceito de História Natural” de 1932 e de seu Kierkegaard: construção do estético, publicado em 1933, até a Dialética do Esclarecimento, de 1944 e os ensaios reunidos em sua Dialética Negativa de 1966. Com efeito, assiste-se à conformação do conceito de "imagem dialética" e de "dialética negativa". Para Adorno, "a conciliação do mito é o tema da filosofia de Benjamin."3 Mito e dialética, portanto, serão os pontos de convergência e de dissenso entre os amigos.

Essa amizade começa em 1923 em Frankfurt, quando Benjamin postulava, para fins de obter o título de Privatdozent, seu Origens do Drama Barroco Alemão do Século XVII. ${ }^{4}$ Apresentado no departamento de Estética da Universidade de Frankfurt, o Drama Barroco, caso aprovado, habilitaria Benjamin à carreira docente e teria evitado sua extrema penúria quando a atividade de ensaísta e crítico da cultura em Revistas, jornais e programas de rádio na Alemanha foi interrompida pela ascensão de Hitler ao poder. ${ }^{5}$ Adorno, com seus vinte anos, e onze mais jovem que Benjamin, talvez tenha sido seu único aluno, pois ele próprio se colocava "na condição de quem recebe"6, daquele que encontrara no "mestre", " $a$ " filosofia. Tal admiração levou Adorno, em sua aula inaugural como professor na Universidade de Frankfurt, a se valer das idéias de Benjamin sem citá-lo. ${ }^{7}$ Em carta de 17 de julho de 1931, referindo-se a uma consideração de E. Bloch sobre a conferência de Adorno, Benjamin elegantemente sugere ao jovem professor que repare a omissão, indicando a fonte no momento da publicação do artigo: 


\begin{abstract}
E agora, uma palavra [...] a respeito da menção ou não de meu nome. Sem a menor ofensa da minha parte - e espero também sem causar a menor ofensa da sua - e após estudar de perto o trabalho, cuja importância mesma me parece justificar em parte questões de outro modo subalternas relativas à autoria (subscrevo a frase sobre um materialismo desvinculado da idéia de totalidade). Mas não poderia tê-la escrito sem nela me reportar à Introdução de meu livro sobre o drama barroco, no qual essa ideia foi expressa pela primeira vez - uma ideia inteiramente inconfundível e, no relativo e modesto sentido em que pode ser reivindicada, uma ideia nova. Eu, de minha parte, seria incapaz de omitir a referência a meu livro. E ainda menos, nem preciso dizer, se me encontrasse em seu lugar. ${ }^{8}$
\end{abstract}

Em seguida, Benjamin aceitaria a proposta de uma dedicatória como compensação. ${ }^{9}$

O renome de Adorno como grande teórico da modernidade procede sob muitos aspectos do "Prefácio de Crítica do Conhecimento" do Drama Barroco, em que Benjamin estabelece a diferença entre Conhecimento e Verdade, diferenciando o método more geometrico, dedutivo ou indutivo, da Ciência, daquele digressivo, próprio ao caráter indefinível da Verdade, assunto da Filosofia. Recusando as pretensões de cientificidade do neo-kantismo, Adorno interroga em seu Kierkegaard: Construção do Estético ${ }^{10}$ as relações entre teoria e realidade, a partir do momento em que o conhecimento foi compreendido nos termos da ciência galilaica que constrói o real segundo a ordem de seus "resultados" (Befunde):

a filosofia não se distingue da ciência [...] por um grau mais elevado de generalidade. Não é nem pela abstração das categorias, nem pela natureza de sua matéria que ela se diferencia da ciência. A diferença central é, melhor dizendo, a seguinte: que a ciência particular aceita seus resultados, pelo menos os últimos e mais profundos de seus resultados, como indissolúveis e fundamentados em si mesmos, enquanto a filosofia considera já o primeiro resultado que lhe é dado como um signo a decifrar. Para dizer claramente: a idéia da ciência é a pesquisa, a da filosofia a interpretação. ${ }^{11}$

Eis por que a Filosofia que pretende apreender o sentido último da realidade não é senão uma forma de melhor legitimá-la, pois a ciência, ao se autonomizar da filosofia e a filosofia ao se aproximar da ciência, não mais percebem suas determinações históricas e seu lugar na divisão social do trabalho. A perspectiva de Adorno é benjaminiana, uma vez que a teoria como interpretação compreende os fatos sociais em seu caráter de "figuras enigmáticas" que exigem deciframento, o contrário da prática estruturalmente apologética do simples registro de resultados. A Filosofia vem a ser uma "hermenêutica" ou até mesmo uma anti-hermenêutica, pois não procura resolver os "signos" na unidade de um significado segundo uma progressão unificadora. Trata-se, ao contrário, de colocá-los em "constelações cambiantes"12, que 
convidam a uma "leitura fisiognômica", na qual "traços e expressões formam um conjunto coerente." 13

Benjamin conhecia a primeira versão do trabalho de Adorno sobre Kierkegaard ${ }^{14}$ e se entusiasmou com o tratamento adorniano do barroco e do tema do intérieur, que Benjamin retomaria ao estabelecer uma analogia entre o Drama Barroco e as Passagens. Por seu lado, Adorno reconhece, em uma carta de 5 de junho de 1935, a influência de Benjamin e, em outra, datada de 2 de agosto do mesmo ano, enumera rubricas do Exposé de Benjamin sobre as "Passagens parisienses" que the são caras: "proto-história do século XIX", "imagem dialética", "relação entre mito e modernidade." Com efeito, Adorno, "pensador do barroco", identifica em Kierkegaard a presença da "imagem mítica", "semelhante a uma petrificação antediluviana", associando suas análises do intérieur à imagem dialética de Benjamin ${ }^{15}$ Aproximando os interiores da "fantasmagoria das mercadorias", Adorno escreve:

todos os aspectos espaciais do intérieur são mera decoração; alheios aos fins que representam, carentes de um valor de uso próprio, as formas provêm e foram criadas unicamente para o próprio quarto em seu isolamento que, por sua vez, só se configura com o conjunto que formam esses elementos. A "lâmpada em forma de flor", o Oriente sonhado que se instala com o jogo do velador da lâmpada e do tapete de junco, o próprio quarto como uma cabine de navio repleta de objetos valiosos, que flutua no oceano - esta fantasmagoria completa de decorações em ruína adquire [...] significado não pela matéria com que foi confeccionada, mas sim a partir do ambiente íntimo que unifica os fantasmas das coisas em uma natureza morta. $^{16}$

Estas "coisas emudecidas" e "imoblilizadas" são as personagens que desalojam o sujeito histórico, constituindo uma história cega, feita de objetos espacializados. Sobre isso, Benjamin anota: ${ }^{17}$

Quer eu me volte à sua apresentação do tema do barroco em Kierkegaard, à sua análise - de fazer época - do intérieur, às maravilhosas citações que você fornece a partir do tesouro técnico do filósofo, repleto de alegorias, ao relato da situação econômica de Kierkegaard, à interpretação da intimidade como cidadela ou do espiritualismo como valor último do espiritismo - sempre me deparo em tudo isso com a riqueza de percepção, mas também com a perspicácia de sua avaliação. ${ }^{18}$

Quando da publicação do livro de Adorno em 1933, Benjamin lhe dedica uma resenha das mais elogiosas em que se lê: "[Este livro] pertence à categoria rara dessas primeiras obras nas quais um pensamento alado se revela no núcleo da crítica.” Quanto a Adorno, sob o fascínio do Drama Barroco Alemão, organiza seus seminários de 1932 na Universidade de Frankfurt tomando-o por base. ${ }^{19}$ 
Nos anos de exílio, o companheirismo intelectual de Adorno e Benjamin se consolida em amizade, apesar da pressão que as circunstâncias históricas acabaram exercendo sobre Benjamin nos últimos anos de sua vida e de sua relação com o Instituto em seus desentendimentos teóricos ${ }^{20}$. Em carta de 17 de março de 1933, Gretel Karplus ${ }^{21}$, futura Sra. Adorno, insiste para que Benjamin deixe Berlim por Paris o mais breve possível. Benjamin o faria para não mais regressar, pois, quando da Ocupação da França por Hitler em 1940, tenta a fuga, mas termina suicidando-se na fronteira entre a França e a Espanha, na cidade de Port Bou rumo a Nova York.

$\mathrm{Na}$ correspondência, além das questões de teoria do conhecimento e de método, o tema da cultura de massa é parte integrante de suas reflexões. Tanto o "declínio da aura" do ensaio "A Obra de Arte na época de sua reprodutibilidade técnica" quanto "a perda da auréola" de "Alguns temas em Baudelaire" serão de grande valia na elaboração do ensaio sobre a "Indústria Cultural como mistificação das massas" de Adorno. Porque na era do capitalismo industrial se ingressa no âmbito da reprodução mecanizada das obras, a reprodutibilidade técnica contribui para o surgimento, sob as ruínas do "recolhimento" e da contemplação estética, de uma nova forma de recepção da obra de arte, o "efeito de choque" das imagens do cinema em seus milésimos de segundo na sucessão perceptiva e a "atenção distraída". Com o fim do "valor de culto" associado à obra de arte, na sociedade de massa cada um se torna um expert, e um "criador", de tal forma que o mercado retira também a missão poética ao poeta que perde sua auréola, abandonando-a à multidão. Qualquer um poderá se apropriar dela e utilizar as insígnias que antes pertenciam à autêntica criação. E isso porque, em ruptura com "o mundo antigo", a modernidade é o tempo do jornalismo e de seus leitores. Em "O cão e o Frasco" de seu Spleen de Paris, o narrador baudelairiano se refere ao "público de rebanho", dirigindo-se a um cachorro que farejou a fragrância de um perfume sem poder apreciá-lo: “Até você, indigno companheiro de minha triste vida, é como o público, a quem nunca se devem apresentar perfumes delicados que o exasperem, mas só imundícies cuidadosamente escolhidas."

Em 1939, Benjamin envia a Adorno, com algumas modificações, seu ensaio "A Paris do Segundo Império em Baudelaire”, sugerindo a publicação da parte referida ao "flâneur". Depois de o ler, Adorno escreve a Benjamin"22: "É difícil assinalar um ou outro aspecto particular, tanto cada momento deste trabalho está igualmente próximo do centro, e tanto é bem-sucedida a construção do conjunto. [...] Nem preciso dizer que trouvaille representa o 
fragmento sobre a auréola". O entrelaçamento de filosofia e pesquisa social foi o que lhes permitiu compreender a nascente indústria da cultura, o que aproxima mas também diferencia os filósofos. A idéia de "perda da tradição" e da aura resultaria, para Adorno, em manipulação sem precedentes das massas, mas, para Benjamin, a existência dessas novas técnicas de reprodutibilidade faria com que, ao mesmo tempo que controladas, as massas pudessem se ver a si mesmas. No ensaio sobre "A obra de arte", em sua versão de $1935^{23}$, Benjamin eliminava a idéia de criatividade e genialidade na produção de uma obra, de valor eterno e de mistério, enfatizando a distinção entre a arte tradicional aurática e a arte moderna reprodutível. Se a obra de arte tradicional nasce em um contexto de culto e se fundamenta nos valores de unicidade, irrepetibilidade e raridade da obra, a arte moderna tem suas raízes no presente, vinculada aos meios técnicos de reprodução que a tornam acessível a todos, sendo, assim, uma arte de massa. Essas idéias presentes no ensaio "A Obra de Arte na época de sua reprodutibilidade técnica", desaparecem no ensaio sobre "A Paris do Segundo Império em Baudelaire". No fascismo, o rádio e o cinema se apoderam rapidamente das massas que perderam a "sensibilidade" à poesia e à experiência que ela propiciava:

\begin{abstract}
o jornal representa um dos inúmeros índices de uma tal diminuição [da experiência]. Se a imprensa tivesse o objetivo de permitir ao leitor incorporar a sua própria experiência às informações que ela lhe fornece, ela teria ido longe. Mas é bem o contrário o que ela quer e que ela obtém. Seu propósito é o de apresentar os acontecimentos de tal modo a que não possam ingressar no domínio em que se fundem na experiência do leitor. Os princípios da informação jornalística (novidade, brevidade, clareza e, sobretudo, ausência de qualquer correlação entre todas as notícias tomadas uma a uma contribuem para este efeito, exatamente como a paginação e o jargão jornalístico ${ }^{24}$.
\end{abstract}

Porque as notícias de jornal exigem não um público de leitores mas de consumidores, esse "embotamento do pensamento" pelo mercado se encontra também nos ensaios de Adorno "Sobre o fetichismo na música e a regressão da audição" de 1938 e no Ensaio sobre Wagner. Nesse sentido, Adorno anota: "o sucesso mercantil de um concerto de Toscanini é o simples reflexo do que se é, paga-se por ele, pelo produto, no mercado: o consumidor adora verdadeiramente o dinheiro que ele gastou em troca da entrada para o concerto" 25 . Circunstância que ocorre justamente pelo esquecimento da tradição que lhe conferia sentido e fazia dele uma experiência de conhecimento. Nesse sentido, Adorno concebe a indústria cultural aproximando a "inflação jornalística do vivido" e o "declínio da transmissão da experiência" na audição musical da teoria do esquecimento e do choque benjaminiana. Pouco 
mais tarde, em carta de 29 de fevereiro de 1940, Adorno se afasta da teoria da "perda da experiência", substituindo-a pela idéia de "reflexo":

\begin{abstract}
posso dizer que todas minhas considerações sobre antropologia materialista, desde que cheguei na América, centram-se na noção de "caráter reflexo" e nossas intenções mais uma vez se comunicam intensamente: pode-se, sem dúvida, ver em seu Baudelaire a história primeva do caráter reflexo. Tive a sensação que o trabalho sobre o fetichismo, o único de meus textos alemães que se fixa um pouco nessas coisas, não lhe agradou muito no seu tempo, seja porque ele toca mais do que devia no mal entendido a propósito da salvação da cultura, seja porque, e bem estreitamente ligado ao que precede, a construção não tenha sido totalmente bem sucedida. Mas se você tivesse a amabilidade de reler o ensaio sob este aspecto [...], talvez você pudesse se reconciliar com alguns desses aspectos.
\end{abstract}

Em uma carta anterior, a de 10 de novembro de 1938, Adorno expressa sua decepção com o ensaio de Benjamin sobre "A Paris do segundo Império em Baudelaire", enfatizando sua "limitação metodológica", o que teria inviabilizado a Benjamin analisar a poética das Passagens. As objeções de Adorno se baseiam no conceito marxista de mediação entre as produções culturais e a vida econômica, entre a arte e o fetichismo da mercadoria. Para Benjamin, a perspectiva marxista é insuficiente para explicar o "sentimento melancólico do mundo", a perda do significado das coisas, pois, para Benjamin, o fetichismo de Marx não favorece compreender as relações entre o orgânico e o inorgânico, entre o trabalho vivo e o trabalho morto, entre a produção e o consumo. Benjamin acolhe mais a visão de Baudelaire e a "curiosa contradição" entre a "teoria das correspondências na natureza e a renúncia à natureza" ${ }^{26}$. Com efeito, a teoria das correspondances implica estabelecer similitudes entre o humano e o natural, sem que isso signifique idealizar o orgânico e naturalizar o humano, na medida em que Baudelaire manifesta, em seus poemas, uma destruição alegórica do orgânico, como em "As Sete Velhas", na presença constante do esqueleto e da morte. Uma tal transferência do humano ao inorgânico não é uma transmissão vertical e hierarquizada da Idéia para a Matéria, porque ao final de uma vertiginosa transição nenhum dos pólos permanece intacto. E, reunindo suas Passagens ao Drama Barroco, Benjamin entrecruza a alegoria baudelairiana e suas correspondências com a ponderación misteriosa de Gracian em sua Agudeza y arte del ingenio. Benjamin considera a ponderación misteriosa como o artifício sutil que introduz um mistério entre os extremos, as contingências ou as circunstâncias, com a finalidade de ponderá-las, para então chegar a uma explicação arrazoada. As contingências constituem a matéria própria aos mistérios porque dão lugar a uma meditação, a uma ponderação: "quanto mais extravagante a contingência, mais realce terá a ponderación [...]. A fonte destas ponderaciones misteriosas é a variedade e pluralidade 
das circunstâncias" ${ }^{27}$. Se na tradição escolástica a contingência permite mostrar que fatos e seres devem sua existência ao Criador, já que poderiam ocorrer de outra forma ou não ocorrer, nos tempos do capitalismo, das leis anárquicas do mercado e do apreço pelo dinheiro, a contingência é risco de não sobrevivência material e psíquica, o que implica angústia existencial, como a da poética de Baudelaire.

O ponto sensível entre Benjamin e Adorno foi, assim, a questão da dialética, "em imagens", para Benjamin, "negativa", que viria a ser, para Adorno. Em outras palavras, faltaria à "feeria dialética" 28 o conceito hegeliano e marxista de "mediação". Isso significa que os "interiores" - em que o indivíduo se retira da vida em sociedade, transformando a realidade em reflexo e a subjetividade se fechando ao mundo externo - correspondem à burguesia oitocentista excluída do sistema produtivo. Por isso, para Adorno, tudo o que se encontra nos interiores são simples decoração, perdem seu valor de uso transformando-se em imagens, de tal modo que o elemento histórico, coisificado nos interiores, é a base de todo movimento dialético. Seu recalque - o que as análises de Benjamin teriam performado ao desconsiderar mediações - produz “ambigüidade”, a oscilação mítica entre história e natureza. Seria essa aparência de um mundo a-histórico e natural o que Adorno criticaria no conceito benjaminiano de "imagem dialética" que manteria, sem vencê-lo, um elemento mítico, na identificação benjaminiana de imagem dialética e sonho - o que Benjamin refutará.

A "feeria dialética" - vitrines, galerias, fotografia, cinema, rádio, dioramas, cocottes, apaches, flâneurs, trapeiros, barricadas, iluminação elétrica, catacumbas, esgotos, bocas do metrô, mercadorias - será substituída pelas "imagens dialéticas", pois estas, diferentemente do mundo maravilhoso fantasmado como incólume pelo romantismo, possibilitam incluir nelas o arcaico e o moderno, o consciente e o inconsciente. Razão pela qual o "elemento destrutivo" da dialética, o negativo que desencantaria o factual e a reificação, não é para Benjamin a Aufhebung de Hegel ou de Marx, uma vez que não é o passado que é destruído pelo presente que o supera, mas são as reservas do passado que destroem aspectos do presente e o abrem ao futuro; sendo incompleto ${ }^{29}$, o passado não poderia ser preenchido no presente. ${ }^{30}$ Porque o diagnóstico do presente são as ruínas e as guerras - de religião no século XVII, do capital na modernidade capitalista - a melancolia do mundo das coisas não será redimida pelo trabalho (como no ideário da ética protestante), ou pelo conhecimento (o projeto de dominação da natureza exterior e interior pela ciência), já que precisamente o conhecimento e o trabalho condenaram a natureza inteira à melancolia e à tristeza. 
Para Adorno, o Trabalho das Passagens é limitado metodologicamente, pois pratica uma "disciplina ascética" na explicação de seus objetos, que carece de fundamentação teórica. Seu "conteúdo pragmático" (a rua, as galerias, as mercadorias) conspira contra a possibilidade de apreensão do projeto de interpretação do século XIX como um Todo. Enquanto Benjamin entrelaça a ascese da imaterialidade e um descenso pragmático para a materialidade, as idéias e as coisas, o alto e o baixo, os contos de fada e a prostituta, a alienação e a desalienação ${ }^{31}$, Adorno identifica nesse método uma elevação mística e um descenso positivista, aliança perversa de motivos metafísicos e materialidade empírica, desconsiderando o conceito dialético de mediação. $\mathrm{Na}$ carta de 10 de novembro de 1938 Adorno escreve:

\begin{abstract}
Você pode entender que a leitura do ensaio "A Paris do segundo Império em Baudelaire", em que um dos capítulos se chama "O flâneur" e outro "A Modernidade" me causou uma decepção? Na sua carta a Max em apenso você aduziu isso como sua intenção expressa, e não seria eu a negar a disciplina ascética a que você se impõe para deixar em aberto a cada passo as respostas teóricas de perguntas e deixar entrever essas mesmas perguntas apenas ao iniciado [...]. "Panoramas" e "rastros", flâneur e passagens, modernidade e sempre-igual, tudo isso sem interpretação teórica - será esse um "material" que pode aguardar paciente pela interpretação sem que seja consumido por sua própria aura? [...]. Parece-me que esta introdução pragmática prejudica a objetividade da fantasmagoria [...], o esboço do primeiro capítulo reduz a fantasmagoria ao comportamento da boêmia literária [...]. A determinação materialista de caracteres culturais só é possível se mediada pelo processo total. ${ }^{32}$
\end{abstract}

Mas, justamente, o método benjaminianao opera uma reviravolta (Umschlag) dialética, em que a dialética hegeliana é détournée, uma vez que não se trata de mediação mas de um acontecimento paradoxal, uma dialética sem mediação tal como se encontra no Drama Barroco, uma dialética alegórica que é reversão entre os extremos. Essa ideia, Benjamin já a formulara anteriormente em carta a Scholem de 28 de outubro de 1931, quando descreve a disposição de pinturas nas paredes de sua nova residência:

por falar de fisiognomia, fico imaginando o que um expert faria do arranjo de quadros de meu apartamento. Embora nem tudo já tenha sido colocado no lugar, percebo com algum choque que há - com a exceção de um pequeno retrato de aniversário de [meu filho] Stefan - apenas quadros de santos na minha cela de comunista.

O que o próprio Benjamin ajeitara sem premeditação o surpreende quando interpreta, na superposição reversível de uma cela de comunista e uma cela de monge, um espaço teológicopolítico dominado por uma imagem ambivalente e enigmática, uma Vexierbild, movente, como a de Jesus que mostra, dependendo do olhar que a contempla, três diferentes 
representações de outros santos. Deve-se compreender a fisionomia metamórfica da face de Jesus como uma alegoria dessa reviravolta sem mediação que define a dialética monádica de Benjamin, em que o rosto de Jesus e dos santos, como o teológico e o político, são os extremos um do outro e ao mesmo tempo permanecem idênticos a si mesmos, mas sempre na latência de um no outro. Se, por um lado, Adorno interpela seu amigo por ser "pouco dialético" e perder a totalidade social, o fará ainda mais quando da aproximação entre Benjamin e Brecht. ${ }^{33}$

No início dos anos 1930, Adorno, Gretel e seu amigo Scholem preocupam-se com essa nova amizade, pois Adorno não tem apreço pelo "marxismo vulgar" de Brecht, "pensamento sem dialética" e "crítica sem teoria", ironicamente denominado "a polêmica pedra filosofal da Dinamarca." Adorno identifica nas análises benjamiananas e em seu otimismo com respeito ao público de cinema tomado como "sujeito político", a influência deletéria de Brecht e de sua teorização do "estranhamento". Na verdade, se trata do papel do intelectual na sociedade. Brecht escreve: "deve-se tentar introduzir um domínio seguro na atitude crítica, distante do gosto da massa e do gosto individual para encontrar um fundamento científico, de modo que a crítica seja sempre algo de controlável." ${ }^{34}$ Não obstante as restrições de Adorno à influência de Brecht sobre Benjamin, o ensaio de Benjamin "O Autor como Produtor" se afasta do espírito da visão bechtiana, pois não se trata de confrontar as obras com a realidade e colocálas a seu serviço, pois as próprias obras constituem um "meio produtivo" que "contém sua própria crítica". Se, para o marxismo de Brecht a arte deve se submeter à sociedade que a explica, para Benjamin são as obras de arte em sua autonomia com respeito ao status quo que, mediadas entre si, podem criticá-lo, abrindo-o a sua inteligibilidade. Em suas análises, Benjamin se reivindica do marxismo e com tanto mais empenho quanto mais ele depende do Instituto de Pesquisa Social que se quer tributário de Marx. ${ }^{35}$

Embora amigos, Adorno e Benjamin estavam conscientes das restrições e perigos potenciais que tal apoio institucional envolvia ${ }^{36}$. Adorno escreve:

Sei muito bem que o Instituto e uma revista que, ainda por cima, é controlada principalmente por Löwenthal terão dificuldades em adotar algo diferente de um trabalho histórico-sociológico. Você não levará a mal, então, se eu quisesse ver o trabalho sobre as Passagens não como uma investigação histórico-sociológica, mas como prima philosophia no sentido que é próprio a você.

Prima Philosophia é o outro nome da metafísica, um retorno ao pensamento pré-crítico, que desobedece o mandamento kantiano "de não fugir para mundos inteligíveis." $\mathrm{Na}$ carta 
marcante de 10 de novembro de $1938^{37}$, na qual Adorno critica "A Paris do segundo Império em Baudelaire" e seu cruzamento de "positivismo e misticismo", ele o faz por lhe parecer um cruzamento enfeitiçado ao qual Benjamin sucumbiria ao interpretar a poética de Baudelaire e estabelecer uma relação sem mediações entre suas metáforas e as condições econômicas do século XIX: o flâneur circula como as mercadorias, as imagens sobre a embriaguez provêm dos impostos sobre o vinho, os trapeiros surgem quando os novos procedimentos industriais deram valor ao que é desperdiçado, e as fantasmagorias de Paris são tecidas pelo mercantilismo dos escritores de folhetim, com o que Benjamin cairia em um "materialismo vulgar" que quer explicar o spleen pela economia de mercado. Adorno escreve:

não receie que eu aproveite [esta ocasião] para montar meu cavalinho de pau. [...] Tento indicar o fundamento teórico de minha antipatia por esse particular tipo de concretude e seus laivos behavioristas. Outra não é a razão disso senão que reputo metodologicamente infeliz dar emprego "materialista" a patentes traços individuais da esfera da superestrutura, ligando-os de maneira imediata, e talvez até causal, a traços análogos da infra-estrutura. [...] Motivados que tenham sido os poemas do vinho baudelairianos pelo imposto sobre o vinho e pelas barrières, a recorrência desse tema nas obras dele não pode ser definida a não ser pela tendência socioeconômica total do período, [...] sensu strictissimo, pela análise da formamercadoria na época de Baudelaire. Ninguém sabe melhor do que eu as dificuldades envolvidas: [meu] capítulo sobre a fantasmagoria de Wagner sem dúvida ainda não se mostrou à altura delas. O Trabalho das Passagens, em sua forma definitiva, não poderá eximir-se dessa obrigação [...]. A abstenção da teoria afeta o material empírico. [...] O tema teológico de chamar as coisas pelo nome tende a se tornar uma apresentação estupefata de meras facticidades. Se eu pudesse falar em termos drásticos, poder-se-ia dizer que seu trabalho situa-se na encruzilhada de magia e positivismo. Esse lugar está enfeitiçado [...]. A impressão que passa todo o seu trabalho, e não só para mim com minha ortodoxia das Passagens, é que nele você se violentou a si mesmo. ${ }^{38}$

A questão de método adquire um sentido específico, uma vez que, para Adorno, a "democratização da arte" e as "massas" contêm o mito sem vencê-lo, com o que Benjamin subestimaria a arte autônoma ao considerá-la mítica, e simultaneamente superestimaria a reprodutibilidade da obra em seu alcance político. Para Adorno, as análises de Benjamin confinavam a arte autônoma no âmbito da mentira e do mito, o que o impedia de reconhecer seu poder liberador no interior do qual pode operar a própria técnica, tudo culminando em que a própria visão de arte reprodutível de Benjamin permaneceria em um isolamento edênico. Adorno desconfiava da idéia benjaminiana segundo a qual à "estetização da política" pelo Fascismo se deveria responder com a "politização da arte.” Adorno observa:

Sua solidariedade com o Instituto, com a qual ninguém se alegra mais que eu próprio, induziu-o a pagar ao marxismo os tributos que não fazem jus nem a ele nem a você [...]. Falo não só por mim, incompetente que sou, mas igualmente por Horkheimer e pelos outros, quando digo que estamos todos convencidos de que seria de extremo benefício não somente à "sua" produção se você elaborasse suas concepções sem tais escrúpulos [materialistas][...]. Afinal de contas, há mais 
verdade na Genealogia da Moral de Nietzsche do que no $A B C$ [do Comunismo] de Bukharin.

Eis por que a Adorno o ensaio "A Paris do Segundo Império em Baudelaire” se apresenta em sua "falta de teoria", transformando seu material empírico em um "acúmulo de pseudo-dados de caráter épico".

Adorno não compreende a visão benjaminiana das Passagens. Elas não contêm oposições dualistas porque não são um espaço de produção, como as fábricas, mas de consumo. Para além da compra e da venda, o que menos importa ao consumidor enfeitiçado é o valor de uso das mercadorias. Para Adorno, o fetichismo da mercadoria deriva do modo de produção, o fetichismo se produzindo no interior da própria fábrica. Para Benjamin, o fetichismo se manifesta não na produção das mercadorias mas em sua circulação, no consumo, com a obsolescência da lógica da mediação social. O consumo empático não difunde alienação e estranhamento, mas "identificação". O fetiche é "móvel”, não se prende ao antropomorfismo do mito, encontrando-se em minerais, máscaras, árvores, portas ${ }^{39}$, estátuas, animais e vegetais. Liberado da corveia da utilidade, o fetiche transita entre o orgânico e o inorgânico, o fetichismo permitindo a Benjamin apreender a influência das mercadorias na cognição dos indivíduos, em seu aparelho perceptivo, e apreciar o fetiche em sua plasticidade e vitalismo. Nessa perspectiva, Benjamin inicia o fragmento "Embaixada Mexicana" de Rua de Mão única, citando Baudelaire: "Nunca passo diante de um fetiche de pau, um Buda dourado, um ídolo mexicano, sem me dizer: aqui está talvez o verdadeiro deus." ${ }^{40}$ Não dualizando verdade e mito, Benjamin não descende do ideário de tradição colonialista ou pós-colonial do progresso que confere ao fetiche um caráter "mítico", como as “imagens arcaicas”, a-históricas e naturalizadas de Klages. Adorno considera as reflexões de Benjamin próximas às análises antropológicas de Klages tão "regressivas" quanto a música de Stravisnki. O fetiche pulsa no ritmo tribal da "Sagração da Primavera"41, produzindo uma fascinação arcaica que paralisa, petrificando a consciência em cultos ctônicos fascistizantes. Eis o que teme Adorno, que Benjamin se aproxime perigosamente do "sono mítico" com o qual as mercadorias envolveram o século XIX e seu capitalismo de consumo. Para Benjamim, diversamente, as mercadorias saem da fábrica e se expõem nas vitrines como nouveautés, incorporando fetichismo e fantasmagoria, investindo a mercadoria de algo a mais que o valor de troca, pois nela há sacralidade, estranhamento, perversão e erotismo, que transfiguram o que é morto e espacializado em algo dinâmico e histórico. A natureza não é estática e idêntica 
a si mesma, como a história não é o lugar do absolutamente novo. Aqui não opera a dialética, o "pensamento do negativo" com sua "transubstanciação alquímica do negativo em positivo" segundo um telos homogeneizador. O desgosto de Adorno com a conceituação benjaminiana o leva a afirmar que o estudo de Benjamin sobre "As Afinidades Eletivas de Goethe" e seu livro sobre o Drama Barroco são "melhor marxismo que suas deduções acerca dos impostos sobre o vinho" de "A Paris do Segundo Império em Baudelaire."

O "estupor da facticidade" com que Adorno critica Benjamin provém da "liberação da mercadoria" da corveia da utilidade, porque há nas coisas factícias um momento humano não criado pelo trabalho, liberado da lógica do valor de uso e do valor de troca. Daí, para Benjamin, o erotismo mesclar-se ao fetichismo no sex-appeal do inorgânico, o que faz vacilar o princípio de realidade, a distinção racionalista entre mito e razão, entre o real e seus fantasmas, tal como Benjamin já o considerava no fragmento "Panorama Imperial: viagem pela inflação alemã”, publicado em 1928 em Rua de Mão única. Época da hiperinflação na República de Weimar, sua base teórica são as categorias de mercadoria e fantasmagoria.

Refletindo sobre a miséria da classe marginalizada, o centro das análises benjaminianas são as condições que impedem o reconhecimento dessa miséria:

o que completa o isolamento da Alemanha aos olhos dos demais países europeus, o que na verdade engendra a atitude de que, ao tratar com os alemães estão tratando com hotentotes (como acertadamente já se disse), é a violência, incompreensível para os de fora e absolutamente imperceptível para os que são prisioneiros dela, com que as circunstâncias, a miséria e a estupidez submetem integralmente as pessoas a forças autonomizadas, como só pode ser a vida dos selvagens submetidos às leis tribais.

As formulações de Benjamin não se pautam pelas condições econômicas objetivas que causam a miséria, mas sim por aquelas que impedem apreendê-la, para talvez - e com o tempo - erradicá-la. À hiperinflação de 1923-1924 sucedeu o período de “estabilidade relativa" de 1925 a 1928.

A hiperinflação, primeiro, e a sensação ilusória de segurança, em seguida, se combinam de forma a produzir uma atrofia progressiva do aparelho perceptivo e cognitivo na Alemanha: "os instintos de massa se tornaram confusos e alheios à vida [...] e, inclusive em casos extremos de perigo, não permitem o uso genuinamente humano do intelecto: a previsão". Vitimado pela inflação, o princípio de realidade não cede ao princípio de prazer mas se dilui nos zeros do papel-moeda que, valendo cada vez menos, os multiplicava. 
Metamorfoseado em brinquedo de criança, o marco alemão construía castelos de papel, ao mesmo tempo em que um pacote de manteiga requeria que o dinheiro fosse transportado em grandes containers ${ }^{42}$. Com a hiperinflação, o desemprego, as multidões de mendigos e os mutilados da Primeira Guerra Mundial, Berlim era o cenário de outras fantasmagorias, das ruínas deixadas pelo Capital. Nesse sentido, a fantasmagoria se revela na inflação como fato empírico e dela decorre a "ambiguidade" como sua característica principal. Categoria epistemológica e moral, a hiperinflação é fonte de desorientação: "Todas as coisas", escreve Benjamin, "em um processo perpétuo de mistura e contaminação, estão perdendo seu caráter intrínseco, enquanto a ambigüidade desaloja a autenticidade."43 Porque a hiperinflação obscurece a consciência, o mundo se povoa de fantamsagorias e fantasmas que dificultam distinguir lucidez e delírio. Mesclando hiperinflação e fantasmagoria, Benjamin decepciona Adorno porque, para Adorno, a verdadeira mediação entre psicologia e sociedade se encontra na produção e no desenvolvimento das forças produtivas. Eis por que Adorno considera que Benjamin substitui a mediação por "motivos teológicos": "o motivo teológico de chamar as coisas pelo nome, conduz tendencialmente para a exposição estupefata da mera facticidade". Se a mediação é produção social, a facticidade é o que isola a coisa singular, que não seria senão um fragmento de realidade, privado de sociedade, um produto inerte e sem sentido algum. Mas, para Benjamin, se a facticidade é rigidez mítica, feitiço, irracionalismo, e o estupor assombro, espanto, surpresa, perplexidade, choque e trauma, ambos reunidos significam um "momento de perigo".

Momento de perigo é risco e angústia. Com efeito, em carta de 4 de março de 1934, é Adorno que se refere aos comentários de Benjamim a seu Kierkegaard, remetendo a seu libreto para ópera, O Tesouro do Índio Joe de Mark Twain, inspirado nas aventuras de Tom Sawyer:

Há semanas carrego comigo uma detalhada carta em torno da questão "Tom Sawyer" já que suas linhas são naturalmente a única coisa de substância que recebi sobre o assunto. [...] Sobre o "Tom" só direi isto: creio que as estrelas que guiam os enfants terribles não são propícias à peça. O que está em jogo aqui é algo bem diverso, e algo que, espero, não seja apenas exclusivo a mim. A linguagem engenhosa não é a engenhosidade das crianças mas aquela da literatura infantil. $\mathrm{O}$ curso da ação, cujo centro é naturalmente a cena da caverna, não me parece tão inofensivo; se não soar arrogante, talvez me seja permitido dizer que na peça fervem ingredientes, que nada é tencionado tal como parece de início e que me valho do modelo infantil para demonstrar coisas bem sérias [...]. A história do nascimento da peça possui algo daqueles momentos de perigo de que você sentiu falta. Certamente não se deve medi-la em confronto com Cocteau nem com o teatro épico; antes, ela se prende de perto a meu livro sobre Kierkegaard. O centro é a quebra do juramento, e o todo um plano de fuga: a expressão da angústia. 
Pouco adiante Adorno lembrará da Infância em Berlim, empregando para o livro o conceito de “estupor” que ele mesmo já utilizara em seu Kierkegaard.

No estupor kierkegaardiano, Benjamin reconhecia "a compreensão mais profunda da relação entre dialética, mito e imagem.” O estupor imerge o sujeito em zonas obscuras de si mesmo nas quais as imagens se unem à dialética, aquelas imagens dialéticas nas quais o passado mais arcaico se mistura a um futuro assim menos desconhecido; quanto às imagens do mito, elas se metamorfoseiam em estupor, pois a estupefação é a única maneira de ingressar no mito. Desse modo, o pensamento de Benjamin não é nem místico, nem positivista, uma vez que Benjamin acompanha os trânsitos entre estupor e facticidade, o cruzamento de "positivismo e misticismo". Surpreende, pois, o diagnóstico adorniano sobre Benjamin, uma vez que as inversões e reversões - entre mito e ratio, iluminismo e superstição, auto-afirmação e auto-negação - constituem também a própria Dialética do Esclarecimento de Adorno e Horkheimer.

Reunindo "estupor" e "facticidade", Adorno fornece a Benjamin a explicitação do significado da "empatia com a mercadoria", da identificação com a matéria inorgânica. Em resposta a Adorno, entristecido ${ }^{44}$ mas revertendo com firmeza a crítica de Adorno a seu favor, Benjamin anota:

De fato, cabe liquidar a indiferenciação entre magia e positivismo, como você formula com pertinência. [O método filológico] da interpretação dos escritos de Baudelaire é aquele exame de um texto que avança por detalhes e fixa magicamente o leitor a ele [...]. O estranhamento, assim você o descreve no seu Kierkegaard, anuncia 'a mais profunda percepção da relação dialética entre dialética, mito e imagem'. Seria de se supor que eu recorresse a essa passagem em meu favor. Mas quero em vez disso sugerir-lhe uma correção (tal como aliás pretendo fazer em outra oportunidade quanto à definição correta de imagem dialética). Creio que se devesse dizer: o estranhamento é um objeto eminente de uma tal percepção. A aparência de facticidades fechadas, que se prende à investigação filológica e sujeita o pesquisador a seu feitiço, desaparece à medida que o objeto é construído em uma perspectiva histórica. As linhas de fuga dessa construção convergem em nossa própria experiência histórica. Com isso o objeto constitui-se como mônada. Na mônada ganha vida tudo aquilo que jazia em rigidez mítica na condição de texto.

A empatia com a mercadoria é o contrário da "consciência ferida" que de fora analisa acontecimentos. Ela rompe com o dualismo orgânico e inorgânico, uma vez que a dialética não é superação que suprime mas que conserva, o que permite dissolver as "facticidades incrustadas em estado de reificação". Filologicamente, Benjamin permanece no "estupor da facticidade" no círculo mágico da Bibliothèque Nationale de Paris, continuando a recolher, 
até o fim, citações densas de estupor pelas quais procurava "sentir e arrebatar o encanto", rompendo, através de citações, ${ }^{45}$ a reificação.

O estupor da facticidade é, também o de Adorno, o do "instante anterior" de seu ensaio sobre Beethoven, o átimo minimal antes da surdez, da solidão e da velhice. Em seu "estilo tardio" convivem, em continuidade e ruptura, o desenvolvimento linear do tempo e o “instante atemporal”, a justaposição do antigo e do novo. Essas composições podem atestar, por seu "inacabamento", negligência ou distração. Certamente, observa Adorno, isso se devia à proximidade da morte: "esta lei [formal]", escreve Adorno,

se revela precisamente no pensamento da morte. A morte só se impõe aos seres vivos, não às obras de arte e, no entanto, só se a viu surgir na arte como uma refração, uma alegoria [...]. Das obras só restam fragmentos, e a comunicação se faz, como em um código secreto através da vacuidade dos espaços de que o compositor se desvencilhou. Tocada pela morte, a mão do mestre libera a massa do material a que estivera habituado a dar forma; suas lágrimas e suas falhas, testemunhas da impotência de seu ego confrontado ao Ente, são sua obra final. ${ }^{46}$

Este "instante final" é o momento do estupor e do perigo que, ao surpreenderem, mantêm em suspenso os indivíduos em uma indecidível expectativa. Entre a vida e a morte, o instante de incerteza é de "desordem nos materiais", aquele antes do qual nada aconteceu e depois do qual tudo estará perdido, nesse não lugar entre Nova York e Port Bou.

\section{NOTAS}

\footnotetext{
${ }^{1}$ A partir da apresentação à edição brasileira do livro Correspondência 1928-1940 Adorno-Benjamin, de autoria de Theodor W. Adorno e Walter Benjamin. Agradecemos enfaticamente à Editora Unesp pela autorização formal desta publicação. Detalhadamente: BENJAMIN, Walter; ADORNO, Theodor W. Correspondência 19281940. São Paulo: Editora da UNESP, 2012, p. 15-46.

${ }^{2}$ Professora titular de Filosofia da Universidade de São Paulo (Usp). Doutora em Filosofia pela Universidade de São Paulo (Usp). E-mail: olgariam@gmail.com.

3 Adorno, T.W., "Charakteristik Walter Benjamin", in Über Walter Benjamin,ed Suhrkamp, Frankfurt, 1970, p.18.

${ }^{4}$ Walter Benjamin e Theodor Adorno encontraram-se algumas vezes em Frankfurt, Berlim e Königstein, mas pouco se freqüentaram, uma vez que Benjamin vivia em Berlim e Adorno em Frankfurt. Em seguida, separados pela emigração, Benjamin é levado a Paris em 1933, ano de ascensão de Hitler ao poder, e Adorno a longos períodos de permanência em Oxford até que se estabelecesse nos Estados Unidos em 1938. Nessa época, os amigos foram constrangidos a organizar, em alguns dias ou poucas horas, encontros para a discussão de seus trabalhos, iniciando, a partir de 1929, "conversas intermináveis", dizia Adorno, sobre o Trabalho das Passagens, cujo projeto Benjamin acabara de redigir.

${ }^{5}$ Esse trabalho fora apresentado na Universidade de Frankfurt ao professor de germanística Franz Schultz que confessa não o ter compreendido. Encaminha-o, então, a Hans Cornelius na área de Estética que, por sua vez, o faz seguir a seu assistente Max Horkheimer, tampouco atinente ao sentido da obra. Se Benjamin considerava Schultz um leitor mediano, o mesmo não poderia ser dito de Georg Steiner que qualificou o prólogo do Drama Barroco como uma das "mais impenetráveis peças em prosa escritas em uma língua moderna". Com efeito, a
} 
obra não obedece aos cânones acadêmicos, pois é uma "escavação arqueológica" nos abismos dos "estados de alma" barrocos, uma vertigem com respeito à qual Benjamin adverte o perigo, aquele de trazer para nosso tempo um mundo espiritual carregado de contradições, a começar pelo luteranismo que manifesta um elemento germânico pagão com sua crença sombria na sujeição ao destino. Cf., Irving Wohlfarth, “ Resentement Begins at Home: Nietzsche, Benjamin and the University", in Walter Benjamin;Critical essays and Recollections, Ed Gary Smith, Cambridge, Mass. MIT Press, 1988. Sobre o barroco, catolicismo e poder, cf. Baumgarten, Jens, Konfession, Bild und Macht, Döling und Galitz Verlag, Hamburg/München, 2004.

${ }^{6}$ Cf Adorno, idem, op.cit. De fato, nos anos 1920 e 1930 Benjamin já tinha sua teoria da alegoria elaborada no Drama Barroco-(1924), os aforismos de Rua de Mão Única (1928), as reflexões sobre a perda da aura das obras de arte no capitalismo industrial no ensaio "A Obra de Arte na época de sua reprodutibilidade técnica”(1935), e sua crítica literária até os exposés da Obra das Passagens sobre a Paris do século XIX (1928-1940). Nesse período, o pensamento de Adorno começava a se formar. Até a morte de Benjamin em 1940, Adorno publicara somente seu livro sobre Kierkegaard:construção do Estético (1933) e alguns ensaios notáveis de crítica musical, nos quais, o próprio Adorno reconhecia a influência do ensaio "A Obra de Arte na época de sua reprodutibilidade técnica". Adorno só se tornou amplamente conhecido ao final da Segunda Guerra Mundial, com a publicação da Dialética do Esclarecimento em 1944, das Minima Moralia em 1951, da Dialética Negativa, em 1966, da Teoria Estética, inacabada, em 1970.

${ }^{7}$ Esse episódio viria a ser associado à carta de 10 de novembro de 1938 de Adorno a Benjamin, na qual Adorno critica o ensaio "A Paris do Segundo Império em Baudelaire” de Benjamin, propondo-lhe reformulá-lo para que fosse aceito na Revista de Pesquisa Social, órgão do Instituo de Pesquisa Social, que nos anos 1950 seria conhecido como Escola de Frankfurt. A correspondência que se estendeu de 1928 a 1940 atesta admiração recíproca, respeito intelectual e apoio de Adorno às dificuldades materiais do exílio de Benjamin a partir do ano de 1933. Nesse sentido, as considerações de Giorgio Agamben sobre a correspondência de Benjamin e Adorno, desfavoráveis a Adorno, são por demais restritivas ao atribuir a Adorno um "marxismo ortodoxo" que o incapacitava alcançar o nível de originalidade de Benjamin. Também Bruno Tackels acusa Adorno de "parasitar" o ensaio sobre a "Obra de Arte". Enzo Traverso, em sua introdução à Correspondência entre Benjamin e Adorno pela Gallimard escreve: "Ao longo das cartas, Adorno se revela um leitor atento dos escritos de Benjamin, extremamente fino e penetrante, a ponto de impor-se a seus olhos como um crítico privilegiado e de certo modo insubstituível, mas certamente não como um inspirador. O paradoxo reside no fato de que[...] [Adorno] adota [a postura] do mediador indispensável; por momentos, de maneira indireta, a do amigo mecenas, e por vezes até mesmo a mais detestável, a do censor." Cf. Adorno et Benjamin: une Correspondance à minuit dans le siècle, prefácio à Correspondance (1928-1940, Ed Gallimard). Cf. Agamben, G. Infância e História, Ed. UFMG; Traverso, E. Correspondance. Quanto à recepção norte- americana da correspondência, ela é mais isenta, uma vez que Susan Buck Morss, em sua Origens da Dialética negativa, reconhece a proximidade de Adorno com respeito aos trabalhos de Benjamin. Mencke, na Alemanha, sugere alguns "empréstimos" de Adonro com respeito ao trabalho de Benjamin, mas indica também influências de Adorno sobre Benjamin. Para uma visão fecunda dessa amizade e análise da recepção da Correspondência, cf. Gilles Moutot em seu Essai sur Adorno (Payot, Paris, 2010).

${ }^{8}$ Cf. Correspondência, editora Edunesp, p. 15.

${ }^{9}$ Cf. Carta de 25.7.1931. A conferência com o título de "Atualidade da Filosofia" só viria a ser publicada nos anos 1950.

10 Adorno, como Benjamin, fracassara na primeira apresentação de seu trabalho de Habilitation sobre Kierkegaard: construção do Estético, pelo parecer desfavorável do mesmo professor Cornelius, que indeferira a tese de Benjamin.

11 Adorno, "Die Aktualität der Philosophie", in Gesammelte Scriften, vol I, ed. Suhrkamp, p 334.

12 Adorno, idem, p 335.

13 Adorno, idem, ibidem.

${ }^{14} \mathrm{O}$ trabalho de Adorno sobre Kierkegaard fora escrito entre 1929-1930, e reescrito entre setembro e novembro de 1932 e publicado em 1933. Cf. Kierkegaard, Konstruktion der Asthetischen, ed. Suhrkamp, Franfurt, 1966.

15 Cf. também Pinheiro Machado, Francisco Ambrosis, Bild und Bewusstsein der Geschichte: Figuratives Denken bei Walter Benjamin, Verlag Karl Alber, München, 2005.

16 Kierkegaard, p 65. O materialismo de Adorno assimila do Drama Barroco a idéia de história natural. No ensaio de 1932, Adorno se refere a esse conceito, decorrente daquele de "segunda natureza" que se encontra na Teoria do Romance de Lukács, no qual um "segmento da história se petrifica" e não mais preenche o mundo de sentido, mas o esvazia. Se na economia a mercadoria escapa ao trabalhador e a produção às leis do mercado e ao fetichismo que o determinam, na vida social os valores se separam dos indivíduos que os produziram, submetendo-os como a "valores eternos", que é o mundo cristalizado das convenções.

${ }^{17}$ Cf. carta de 01.12.1932.

${ }^{18}$ Cf. Correspondência, p 29. 
19 Cf. Adorno Seminar vom Sommersemester 1932 über Benjamins Ursprung des deutschen Trauerspiels. Franhurter Adorno Blatter IV, ed. Theordor W. Adorno Archiv, München, edition text+Kirtik, 1995.

${ }^{20}$ As cartas trocadas entre Adorno e Benjamin são, por vezes, repletas de humor. Assim, quando se referem a Sohn-Rethel, estudioso original do pensamento de Marx que muito admiravam, os amigos o designam como "o mago da economia" e "So’n Rätsel" - "enigma-e-tanto". Mas o tom geral da correspondência é cerimonioso, diversamente da correspondência entre Gretel Adorno e Benjamin, em que se tratam por nomes afetivos. Assim, Gretel é Felizitas, Benjamin é Detlef. Para Benjamin, Gretel "tem um ar de Katharine Hepburn."

${ }^{21}$ Benjamin a apresentara a Adorno nos anos 1920 e somente após quatorze anos de noivado Gretel Karplus será a Sra. Adorno. Cartas comoventes em que se mostram um ao outro sem reservas, nelas se encontram todos os esforços de Gretel Adorno em apoio a Benjamin para buscar-lhe auxílio financeiro, já nos anos anteriores à emigração. Em carta de 1933, Benjamin se refere a suas mais significativas amizades, com Scholem e Gretel, designando o lugar dessa correspondência em sua vida; comparando seus correspondentes a uma orquestra da qual Gretel é o "primeiro violino". Sabedora de quanto Benjamin estava ligado a Paris, procura convencê-lo a partir, enaltecendo a cidade de Nova York e os encontros que lá teria, um pouco antes de ela mesma e Adorno deixarem Oxford por Nova York. Em carta de 07.03.1938 Gretel escreve: "Você nem pode imaginar como eu gostaria que você também estivesse aqui [em Londres]. Meu único receio é que as Passagens lhe agradem tanto que você não vai jamais querer se separar dessa arquitetura esplendorosa".

$22 \quad$ Cf. Carta de 29 de fevereiro de 1940.

${ }^{23}$ Sobre as quatro versões do ensaio sobre a "Obra de Arte" de Benjamin e a história de suas reelaborações à luz das críticas de Adorno, cf. Barbara Chitussi in Immagine e Mito: um carteggio tra Benjamin e Adorno, ed. Mimesis, Milano, 2010 e Taísa Plaçharres. Aura: a crise da arte em Walter Benjamin, ed. Barracuda, SP, 2006.

${ }^{24}$ Benajmin, Charles Baudelaire, um lírico no auge do capitalismo, trad. João Carlos Martins Barbosa e Hemerson Alves Baptista, in Obras Escolhidas III, ed. Brasiliense,1989.

${ }^{25}$ Adorno, GS 14, p.24-25.

${ }^{26}$ Cf. "Parque Central", in Charles Baudelaire, um lírico no auge do capitalismo, Obras Escolhidas III, op cit.

${ }^{27}$ Gracian, B. Agudeza y arte del ingenio, in Obras Completas, vol. II, Biblioteca Castro, Madrid, 1993, pp 355-

357. Os discursos VI e XI são dedicados à "ponderación misteriosa."

${ }^{28}$ Esta expressão, utilizada por Benjamin em sua primeira versão de Paris, a Capital do Século XIX, desaparece na reescrita de Paris, capital do século XIX.

${ }^{29}$ Em carta de 16 de março de 1937, Horkheimer já lera algumas partes das Passagens, indicando seu desacordo com respeito à idéia de que o passado é incompleto: "a injustiça passada já aconteceu e foi completa. Os que foram assassinados foram assassinados. No fim, sua afirmação é teologia. Se se levar inteiramente a sério a falta de fechamento [do passado] deve-se acreditar no Juízo Final". Para Horkheimer, fazer justiça ao passado é reconhecer que ele e suas injustiças são irreparáveis, e o luto deve ser feito, qualquer outra postura é idealista e teológica. Benjamin aceitaria e ao mesmo tempo negaria as afirmações de Horkheimer dizendo que a História não é tão somente uma Ciência mas uma forma de memória (Eindenken). Se o passado só existe para a memória, ele pode ser modificado pela recordação, o que é completo se faz incompleto e o completo incompleto. As esperanças irrealizadas do passado podem ressurgir.

${ }^{30}$ Cf. Eduard Fuchs. "Der Sammler und Historiker", in Gesammelt Schirften, Suhrkamp,Frankfurt, 1972-1989.

${ }^{31}$ Benjamin considera a prostituta como a herdeira das fadas da literatura fantástica, pelo prazer desinteressado que ela promete, desvinculado da procriação e do status quo da família. (Cf.Rua de mão única, op.cit)

${ }^{32}$ Cf. Correspondência, pp. 358-359.

${ }^{33}$ Asja Lacis, diretora de teatro infantil na URSS, apresentara Benjamin a Brecht em 1929.

${ }^{34}$ Cf. E. Wizisla, Benjamin und Brecht.Die Geschichte einer Freundscaft, , Shurkamp, 2004, p.314.

35 Desde pelo menos 1932, Benjamin procurava ser aceito pelo Instituto. Em novembro desse ano escreve a Adorno: "é extremamente importante que eu encontre Horkheimer e por uma razão precisa. Se alguma coisa pudesse, ou pode ser feita pelo Instituto para financiar meu trabalho, este é o momento, um momento em que meu trabalho está sendo sabotado por todos os lados.” Em 1935 o Instituto ofereceu-lhe uma pequena bolsa para seu Trabalho das Passagens, no ano seguinte o soldo aumenta um pouco e, a partir de 1937, Benjamin integra oficialmente a lista dos membros do Instituto.

36 Se Adorno se preocupa com a "marginalidade" de Benjamin face ao marxismo do Instituto, teme também a sua. Em carta de 25 de abril de 1937 a Benjamin, Adorno refere-se a Marcuse como um pedante "professor de escola primária" (Oberlehrer), preocupado com a possibilidade de Horkheimer considerá-lo um incurável crítico, "irritante e perverso", de quase todos os membros do Instituto, de Löwenthal a Erich Fromm, de Neurath a Lazarsfeld.

37 Esta foi a carta que provocou o desconforto nas relações entre os amigos. Da correspondência de 1931 àquela posterior a 1938, passa-se de uma intimidade afetuosa e de segurança intelectual de quem "dá" e quem "recebe", a um receio de exprimir os pensamentos que pudessem ser mal interpretados por Adorno. No contexto histórico do Nazismo, da guerra e do exílio, os constrangimentos materiais e a vulnerabilidade de Benjamin que dependia 
do apoio econômico do Instituto, determinaram nesse momento uma inversão de papéis. Benjamin não mais criticaria os trabalhos de seu correspondente que agora o criticava.

38 Em seu livro Sobre Walter Benjamin, publicado em 1951, Adorno identifica na tendência de Benjamin em adequar seu pensamento às categorias marxistas uma "traição a si mesmo". "Identificação com o agressor" é a expressão de que se vale Adorno quando se refere ao conceito benjaminiano de crítica em Rua de Mão Única. Adorno avalia que o "gosto da proximidade" que as massas têm com as coisas, e que destrói a "aura" das obras de arte e também a possibilidade de crítica, seria uma concessão de Benjamin à "democratização" do acesso às obras de que as massas estavam excluídas anteriormente. Adorno anota: "[Benjamin] nega o conceito de crítica e o contrasta a uma práxis coletiva de que ele mesmo tinha horror, deixando-se conduzir pelo mais familiar espírito do tempo."(p. 32). Já anteriormente, em carta de 6 de novembro de 1934, Adorno manifestara seu descontentamento com uma resenha elogiosa de Benjamin de escritos de Max Kommerell, historiador de literatura, que Adorno conhecera na Universidade de Frankfurt. Em 1968, Adorno se expressa sobre esse malestar do passado: "Conheci Kommerell pessoalmente, e recebemos nossos diplomas de pós-doutorado em Frankfurt quase ao mesmo tempo. Mas nossa amizade era bastante superficial - as diferenças políticas de então eclipsaram tudo a tal ponto que nenhum verdadeiro contato entre mim e um indivíduo decididamente tão de direita poderia se estabelecer; na época eu o via como um fascista extremamente bem dotado, é verdade, e tenho certeza de que ele também não me suportava. Hoje tudo isso soa estranho, mas antes de 1933 as coisas eram bem diversas[...]. Nunca pude entender a admiração que Benjamin nutria pelos seus inimigos." (carta inédita a Golffling de 04/01/1968). Cf. Correspondência, ed. Edunesp, p.75.

${ }^{39}$ Cf. o arquivo "Paris antiga, catacumbas, Demolições, Declínio de Paris", in Passagens,trad. Irene Aron e Cleonice Mourão, ed. UFMG, B.H, 2006.

${ }^{40}$ Benjamin, W., Rua de mão única, trad. Rubens Rodrigues Torres Filho e José Carlos Martins Barbosa, Ed. Brasiliense, 2000, p.17.

${ }^{41}$ Cf. Adorno, Philosophie der neuen Musik, in Gesammelte Schriften, vol. XII, ed. Suhrkamp, Frankfurt, 1999; cf. ainda Ensaios sobre Música e Filosofia, org. Rodrigo Duarte e Vladimir Safatle, ed. Humanitas, SP, 2007.

${ }^{42}$ Com a desvalorização da moeda e o preço das mercadorias alterando-se diversas vezes em um mesmo dia, perderam-se as referências mínimas dos preços. Historiadores do período anotaram que não mais se conseguia dizer se uma caixa de fósforos valia um ou mil marcos. Para a iconografia do período, cf. Wolf Von Eckhardt and Sandler L.Giulman, Bertolt Brecht's Berlin, Anchor Books, Garden City, New York,1975.

${ }^{43}$ Cf. Benjamin, Rua de Mão Única. Obras Escolhidas II. Trad. Rubens Rodrigues Torres Fiho e José Carlos Martins Barbosa. Ed. Brasiliense, 2000.

44 Adorno recebera o ensaio "A Paris do Segundo Império em Baudelaire" para publicação na Revista do Instituto de Pesquisa Social, e de sua aceitação dependia a continuidade do financiamento das pesquisas de Benjamin. Seu atraso em responder inquietou Benjamin que escreve, quando de sua resposta a Adorno: "O recebimento da carta, em sua demora, como você pode imaginar, preocupou-me muito; e [quando era iminente sua chegada] meus olhos caíram um dia num capítulo de Regius. Sob a rubrica 'À espera', lê-se: 'A maioria das pessoas espera cada manhã por uma carta. Que a carta não chegue, ou contenha uma negativa, sucede em geral àqueles que já estão tristes.' Quando dei com esta passagem, estava triste o suficiente para descobrir nela um palpite e um pressentimento sobre sua carta." Como na carta Adorno sugere a Benjamin rever o texto e não publicá-lo em nenhuma de suas partes, Benjamin, sob a pressão de suas condições de vida, escreve a Adorno: "Permita-me acrescentar uma palavra franca. Creio que seria bem pouco útil ao "Baudelaire" se nenhuma parte do texto - fruto de um esforço que não me seria fácil comparar com meus esforços literários anteriores - tivesse acesso à revista. Primeiro, a forma impressa permite ao autor um certo distanciamento do texto, o que é de incomparável valor. E, depois, permite que o texto nesse formato possa ser aberto à discussão, o que - por insuficientes que sejam seus parceiros locais - poderia compensar em certa medida o isolamento em que trabalho." (pp. 371-372).

${ }^{45}$ Cf. a tese n. 3 em "Sobre o Conceito de História" in Obras escolhidas I. Trad. Sérgio Paulo Rouanet, ed. Brasiliesne, 1995. A citação tem também o sentido de "chamar para um tribunal", de "convocação". Para Benjamin não é a História o tribunal que, à maneira de Hegel, julga os homens, mas são os homens que julgam a História.

46 Adorno, “Spätstil Beethovens”, in Moments Musicaux, ed Shurkamp, 1964, p.15. 